\title{
The endemic Bawean Serpent-eagle Spilornis baweanus: habitat use, abundance and conservation
}

VINCENT NIJMAN

\section{Summary}

The Bawean Serpent-eagle Spilornis baweanus is endemic to the $190 \mathrm{~km}^{2}$ island of Bawean in the Java Sea (Indonesia) where it is the only resident diurnal raptor. A 15 day study in 2002 revealed that the species is present in small numbers throughout the island. The eagle's abundance was assessed by an island-wide survey and by sampling $28 \mathrm{I} \mathrm{km}^{2}$ plots covering five habitat types. There was a strong positive correlation between abundance and contact time in plots. Compared with other habitat types, the number of, and contact time with, serpent-eagles was higher in tall forest. The species was not recorded in mangrove and coastal forest. There was no correlation between the eagle's abundance and the nearest distance to villages. Based on the distribution of forest and the abundance of adult pairs within these forests, the available habitat totals $92 \mathrm{~km}^{2}$, in which some $60-75$ adult serpent-eagles remain. Semi-structured interviews with the islanders revealed that recreational hunting poses the largest threat to the survival of the Bawean Serpent-eagle, and that the increase in recreational hunting was a relatively recent phenomenon. The forest on Bawean, including that in two reserves, is poorly protected and illegal logging and burning are widespread. The low degree of habitat protection, the severe threat posed by hunting and the very small population size of the eagle qualify the species to be included in the IUCN Red List as Critically Endangered. In order to safeguard the Bawean Serpent-eagle hunting must be stopped immediately and the remaining habitat needs to be better protected. This is probably best achieved by a conservation body in which local and regional authorities and NGOs cooperate.

\section{Introduction}

The Bawean Serpent-eagle Spilornis baweanus is one of a group of 12 Indomalayan serpent-eagles, many of which are single-island endemics (Ferguson-Lees and Christie 2001). In November 1907 W. L. Abbott collected the first four specimens on the island of Bawean in the Java Sea, halfway between Java and Borneo, and these were later described as a taxon most closely related to the Crested Serpent eagle from Sumatra (Oberholsen 1917) now known as S. cheela malayensis (Stresemann 1959b). As 'lumping' was the fashion of the day, virtually all Indomalayan serpent-eagles were considered to be merely subspecies of the wide-ranging Crested Serpent-eagle. In the years following, taxonomists repeatedly pointed to a number of diagnostic morphological differences between these alleged subspecies (e.g. Meise 1939, Stresemann 1959a, Hoogerwerf 1962) but failed to appreciate the real evolutionary status of the group, which remained in dire need of revision (Brown and Amadon 1968, Burton 1989). Amadon (1974: 162), for instance, noted that "There would be little doubt that some of these well-differentiated taxa are species... One hesitates, however, to set 
up as species six to eight forms which most authors in recent years have treated as subspecies". Ferguson-Lees and Christie (2001) recently argued that many of the small-island taxa are best considered valid species, endemic to their respective islands. Recognizing the need for a more proper phylogenetic analysis of the group, but assuming that Ferguson-Lees and Christie (2001) treaty will be followed, the Bawean Serpent-eagle has one of the smallest distribution ranges of all raptors.

Hardly anything is known about the biology or status of the Bawean Serpenteagle (Ferguson-Lees and Christie 2001). Between 1892 (Vorderman 1892) and 1969 (Sitwell 1970) at least eight (ornithological) expeditions were mounted to Bawean (Nijman 2004b), but hardly any data concerning the Bawean Serpent-eagle were published. The last data collected on the eagle date back to 1954 when Hoogerwerf (1962, 1967) conducted an ornithological survey of the island and collected four specimens, but few biological data were published (cf. Hoogerwerf 1965).

With the aim of obtaining the first data on the ecology of the Bawean Serpent-eagle and assessing its conservation status, I visited Bawean in 2002. More specifically, I set out to document the distribution and estimate the abundance of the eagle on the island, to quantify its habitat use, and to assess the level of threat the eagle faces.

\section{Methods}

Study area

Bawean is a small island of approximately $190 \mathrm{~km}^{2}$ (or $c .15 \mathrm{~km}$ across), situated in the Java Sea $120 \mathrm{~km}$ north of the island of Java (Figure 1). The island consists of the remains of an old volcano and has several peaks $>600 \mathrm{~m}$ elevation, the highest being Mount Besar at $646 \mathrm{~m}$ elevation (not $886 \mathrm{~m}$ : Ferguson-Lees and Christie 2001). The interior is still largely forested, but the more fertile plains are all converted into agricultural land. Until the middle of the fourteenth century Bawean was not inhabited by humans and, based on linguistic similarities, was then populated by people from the nearby island of Madura (Blouch and Admosurdirdjo 1979). The island is now densely populated (c. 340 people $\mathrm{km}^{-2}$ ), with most people living in villages in the coastal plains. The islanders are largely dependent on fishing and farming, but a relatively large proportion of the population are immigrant workers to Singapore and Malaysia.

Bawean has three strict nature reserves (cagar alam), two of which are on small offshore islets. The one nature reserve on the main island covers a mere $7 \mathrm{~km}^{2}$, and is centred around a small mountain lake (Telaga Kastoba). Additionally some $38-46 \mathrm{~km}^{2}$ of forest is protected in the island's wildlife reserve (suaka margasatwa); the reserve is poorly demarcated in the field and its size varies between sources (e.g. MacKinnon et al. 1982, Whitten et al. 1996, N. Syamsi pers. comm.). Faunistically Bawean is best known for its endemic Bawean Deer Axis kuhlii, reputedly the rarest deer in the world (Blouch and Admosudirdjo 1979). Only a small number of endemic taxa have been described from the island, and most animal and plant species of Bawean also occur on Java (Hoogerwerf 1967, Blouch and Admosurdirdjo 1979).

\section{Raptor censusing}

I visited the island for 15 days in September-October 2002. Bawean is encircled by one main road and there are several smaller roads and numerous tracks running 

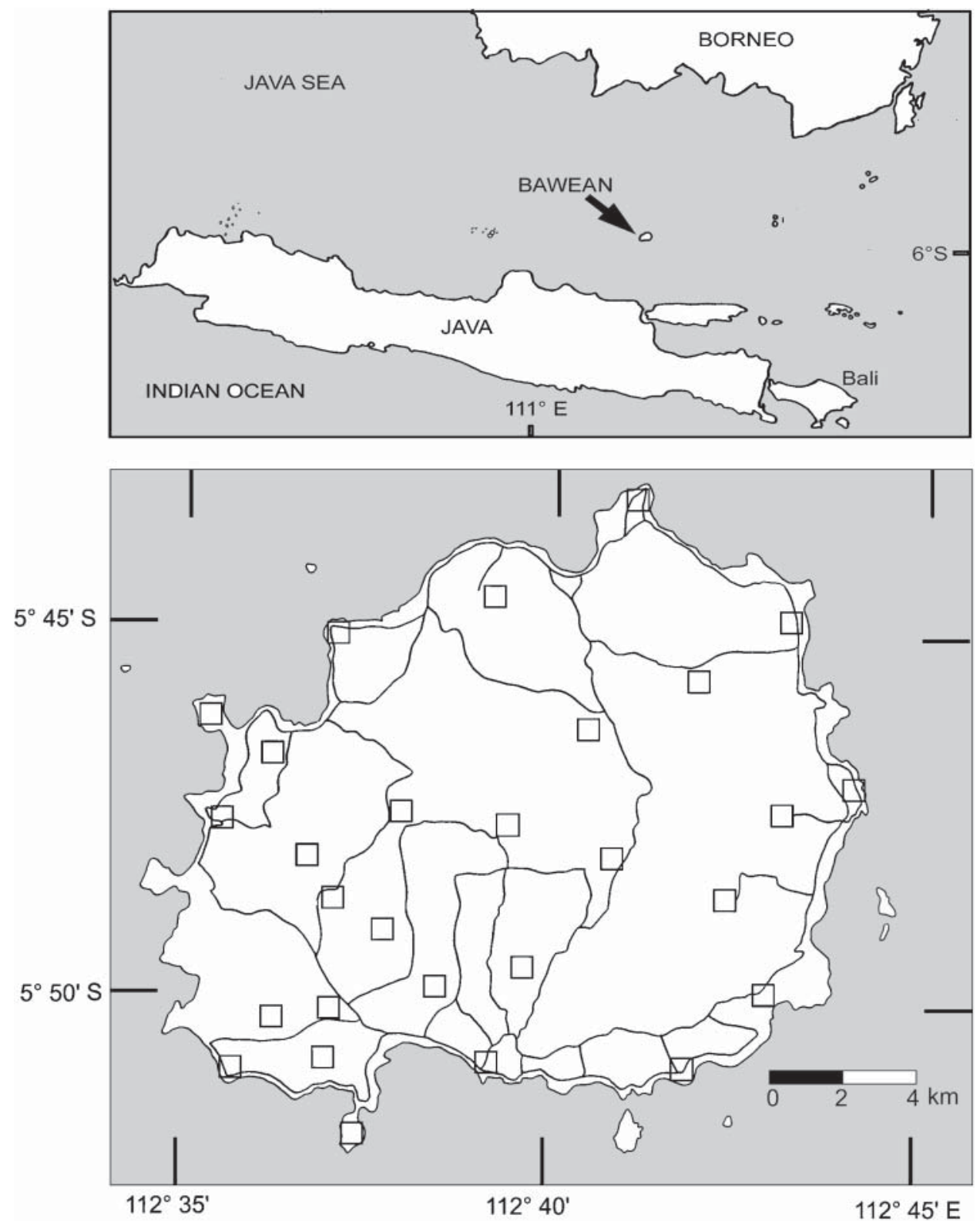

Figure 1 . The island of Bawean showing the survey routes and sampling plots.

through the interior, allowing access to almost the entire island. Data on the Bawean Serpent-eagle were collected during surveys across the island following roads, tracks and forest trails, mostly on foot and sometimes using motorbikes. Bawean Serpenteagles proved to be the only resident eagle on the island and its piercing vocalization and soaring made it relatively easy to detect. Upon encounter, data were collected on exact location and altitude (obtained with a GPS receiver), habitat and behaviour of 
the eagle (flight mode, vocalizations, interactions with other birds, etc). I recognized five distinct habitat types, which are detailed below:

- Mangrove and coastal forest: Mangrove tidal forest comprised mainly of Sonnerati alba, Rhizophora macronata, Bruguiera cylindrica with Acrostichum aureum as undergrowth, whereas the coastal forest was characterized primarily by Barringtonia racemosa trees. Small stretches of Nypa fruticans fringe the coast and estuaries, especially on the shallower parts of the island.

- Cultivated land: This consists primarily of rice fields, with smaller areas covered in grassland, gardens and village areas.

- Teak plantations: Monoculture teak Tectona grandis plantations with sparse undergrowth locally alternate with small patches of alang-alang Imperata cylindrica grassland. Strips of gallery forest are often left along watercourses and steep valleys.

- Shrubland and degraded forest: This includes abandoned gardens where low shrubs and weeds form a pioneer vegetation towards new secondary forest.

- Tall forest. Primary and mature secondary forest often with large figs Ficus variegata and F. septica, Podocarpus rumphii and several Eugenia species.

In addition to the general survey, $28 \mathrm{I} \mathrm{km}$ plots were sampled for $\mathrm{I}$ hour each between 08 hoo and 12 hoo from a single vantage point overlooking the plot. A I hour sampling period proved to be adequate to assess the eagle's abundance as, for instance, the average number of eagles per plot did not increase with increasing sampling duration (Figure 2). The locations of the plots were chosen following a stratified random technique covering all major habitat types and all parts of the island (Figure 1 ). Each plot was positioned such that it mostly covered only one of the recognized habitat types. The overland distance to the nearest village or hamlet was estimated to the nearest $100 \mathrm{~m}$. Data were collected on the numbers of the serpent-eagles and the total amount of time they spent within the plot.

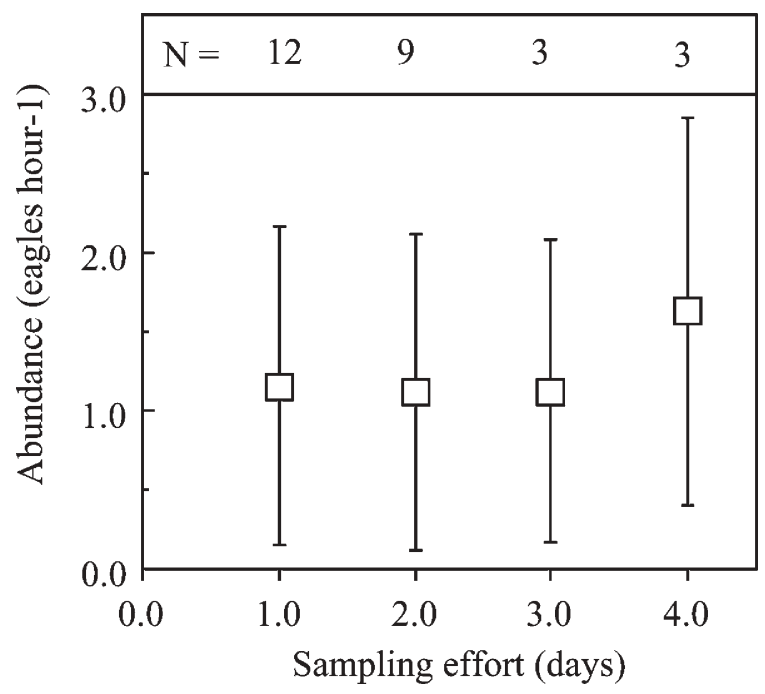

Figure 2. Abundance (mean $\pm 1 \mathrm{SD}$ ) of Bawean Serpent-eagles Spilornis baweanus in $1 \mathrm{~km}^{2}$ sample plots in relation to sampling effort. 


\section{Threat assessment}

A qualitative assessment was made of the state of the eagle's habitat and human attitudes towards its conservation. Data were collected on threats to both the forest and the island's avifauna, including logging, firewood collecting, burning and hunting, and the degree of protection the strict nature reserve and the wildlife reserve offered.

Additionally, data on threats were collected through semi-structured interviews more than 20 minutes long, conducted in Bahasa Indonesia with people who demonstrated knowledge of the natural history of the island or who were professionally involved in law enforcement and nature conservation. These included collectors of forest products/hunters (4 interviewees), farmers (3), army and police (2) and governmental officials (forestry department, department of agriculture; 6). To ensure independence of data each interviewee was questioned separately. After some initial questions on personal details (age, place of birth, occupation, etc.) and general wildlife issues, the interview focused on past and present abundance of serpent-eagles, threats to the eagle, whether there has been a change in its abundance and, if so, what the possible causes might be.

\section{Analysis}

Home range sizes of Bawean Serpent-eagles were estimated with a convex polygon method by plotting all sightings of four pairs (often identifiable by their moulting pattern on wings and/or tails) on a map (scale 1: 25,000). Given the limited time available for mapping home ranges (2-4 days per pair) these are almost certainly underestimates, and as such provide only an indication of densities at which the species may occur.

All data were checked to determine whether or not they significantly departed from a normal distribution; if they did, data were transformed so as to approach a normal distribution more closely. The relationship between the contact time with eagles and the number of eagles recorded on the plot was explored with a simple linear regression model. The influence of habitat type on Bawean Serpent-eagle distribution was assessed firstly by comparing characteristics of plots where the eagle was recorded with those where it was not. Secondly, the eagles' frequency relative to the five habitat types was assessed, using a $\chi^{2}$ distribution to test for differences in the distribution of records by habitat. Expected values were generated based on a random distribution of birds proportional to the amount of each habitat sampled. Yates' correction for continuity was applied when appropriate (Sokal and Rohlf 1995). Significance was assumed when $P<0.05$ in a two-tailed test. Means are reported $\pm_{1} \mathrm{SD}$.

\section{Results}

\section{Distribution and abundance}

During the survey I had 49 encounters with Bawean Serpent-eagle, or $3.3 \pm 2.5$ birds per day. The largest number of eagles observed in one day was eight. Total visual contact time was 213 minutes or almost 15 minutes per day. Bawean Serpent-eagles were mostly observed as single birds $(62 \%)$ and pairs $(25 \%)$ and more rarely in groups of three $(9 \%)$ or four $(3 \%)$ birds. The eagles are highly vocal and $63 \%$ of 
encounters involved one or more birds calling. Most were observed between o8hoo and 12 hoo (Figure 3) and, generally, when the weather was clear and sunny they could be seen soaring from afar. Hence, the Bawean Serpent-eagle is an easily observable bird, allowing an accurate assessment of its presence.

Quantitative assessment of abundance using data from the $1 \mathrm{~km}^{2}$ plots indicates that, in those plots where the species presence was confirmed, on average $1.8 \pm 1.0$ eagles per plot were present. Average contact time per plot was $9.7 \pm 14.2$ minutes. There was a strong positive relationship between the number of eagles in a plot and total contact time with eagles $\left(R_{\text {adj. }}{ }^{2}=84.7 \%, F_{1,10}=61.9, P<0.001\right)$ and the number of eagles in a plot and contact time per individual eagle $\left(R_{\text {adj. }}{ }^{2}=58.8 \%, F_{1,10}=16.7\right.$, $P=0.002$ ) (Figure 4). As the number of eagles per plot increases, the contact time with each individual eagle increases. Contact time per plot can thus be used as a proxy for abundance in exploring habitat usage.

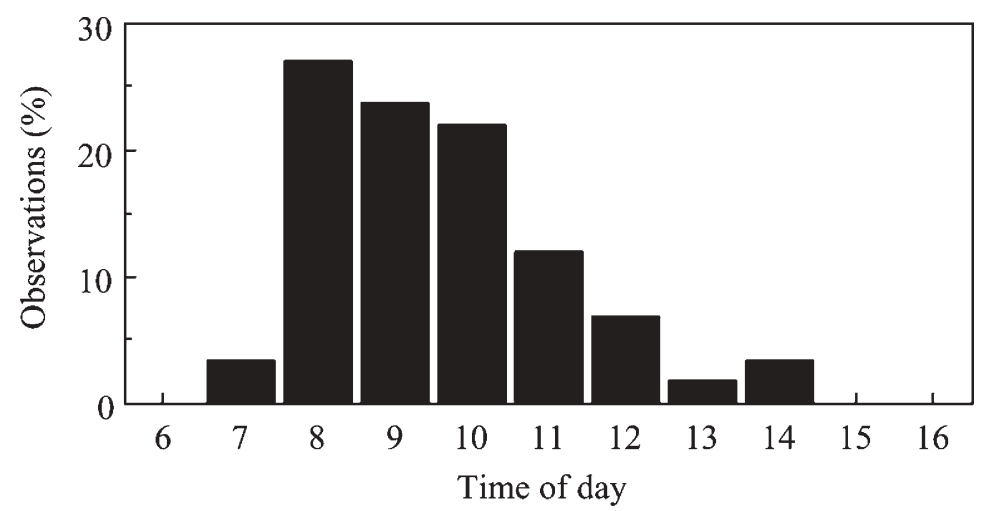

Figure 3. Distribution of time of first encounters with Bawean Serpent-eagles Spilornis baweanus $(n=49)$ in September-October 2002.

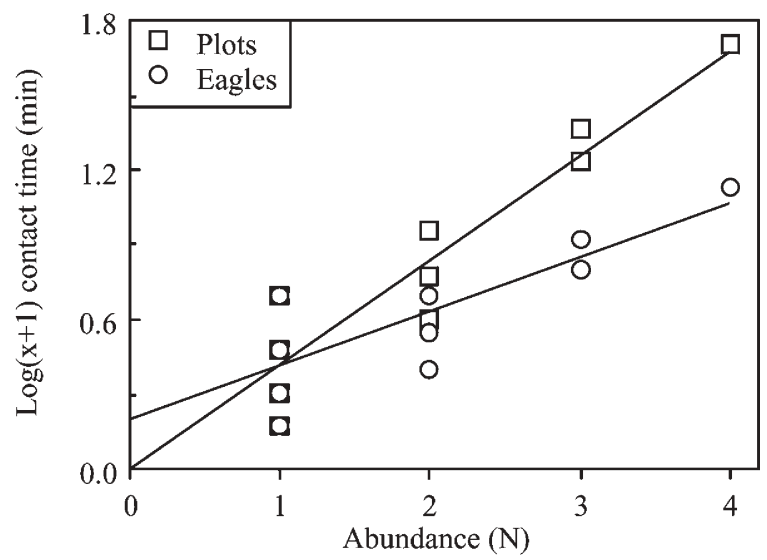

Figure 4. Linear regression of abundance of Bawean Serpent eagles Spilornis baweanus (expressed as individuals per sample plot) on contact time per hour on $\mathrm{I} \mathrm{km}^{2}$ sample plots: 'Plots' refers to the contact time with the eagles as observed on individual plots, whereas 'Eagles' refers to the contact time per individual eagle. 
Two adjacent pairs in the north-western part of the island had a minimum home range of 4.0 and $3.5 \mathrm{~km}^{2}$ ( $n=2$ days), respectively, whereas two pairs in the south had minimum home ranges of $5.5 \mathrm{~km}^{2}\left(n=4\right.$ days) and $6.0 \mathrm{~km}^{2}(n=3$ days). Home ranges of all pairs were covered in a mixture of tall forest, some shrubland and degraded forest and cultivated land. These home ranges were not exclusive, however, as other singles and pairs used part of these areas as well.

\section{Habitat use}

Most eagles were observed in or above tall forest (49\%) and to a lesser degree shrub and degraded forest $(27 \%)$, followed by cultivated land $(16 \%)$ and teak plantations $(8 \%)$. Birds were observed in or above neither the Nipa palm stretches nor mangrove forest or coastal forest. Even in areas where the forested hills bordered the sea very closely, soaring eagles did not once fly above the sea.

A similar preference for tall forest was observed in the $1 \mathrm{~km}^{2}$ plots (Table $\mathrm{I}$ ). Records of Bawean Serpent-eagles in four habitat types (shrub and degraded forest and teak plantations were pooled because of low expected values) were not equally distributed $\left(\chi^{2}=22.9, P<0.001\right)$. In terms of both the absolute number of eagles and contact time per plot, Bawean Serpent-eagles occur significantly more in tall forest compared with the other three habitat types combined (number of eagles: $\chi^{2}=18.5$, $P<$ o.001; contact time: $\left.\chi^{2}=149.0, P<0.001\right)$. Conversely, mangrove and coastal forest had significantly fewer eagles than the other habitat types combined (number of eagles: $\chi^{2}=58.7, P<0.001$; contact time: $\chi^{2}=3$ 10.0, $\left.P<0.001\right)$.

Bawean Serpent-eagles were recorded from sea level to $>500 \mathrm{~m}$ above sea level (a.s.l.), and the elevation of plots where the species was present ( $181 \pm 135 \mathrm{~m}$ a.s.l.) was significantly higher than that of plots where the species was absent $(75 \pm 63 \mathrm{~m}$ a.s.l.) ( $t$-test using log-transformed data: $t=2.38$, d.f. $=25, P=0.025)$. Whether or not altitude per se influences the distribution is not clear because, for instance, tall forest plots (the species' preferred habitat) were situated at significantly higher elevations than the other habitat types combined ( $t$-test using log-transformed data: $t=2.35$, d.f. $=25, P=0.027$ ). In plots where the species' presence was confirmed, there was no correlation between the plot's altitude and number of eagles per plot $\left(F_{1,10}=0.10\right.$, $P=0.75)$ or altitude and contact time per plot $\left(F_{1,10}=0.09, P=0.77\right)$.

Bawean Serpent-eagles were frequently observed near villages and distance to the nearest village or hamlet for plots where the species was present $(637 \pm 709 \mathrm{~m})$ was not different from that for plots where the species was absent $(866 \pm 1,017 \mathrm{~m})$ ( $t$-test: $t=0.10$, d.f. $=25, P=0.90$ ). For those plots where the species was present, abundance showed no correlation with the distance to the nearest village $\left(F_{1,10}=0.90, P=0.37\right.$

Table 1. Habitat use of Bawean Serpent-eagles Spilornis baweanus.

\begin{tabular}{lclcc}
\hline Habitat (no. of plots) & $\begin{array}{l}\text { Altitude } \\
\text { (m a.s.l.) }\end{array}$ & $\begin{array}{l}\text { Distance to village } \\
(\mathrm{km})\end{array}$ & $\begin{array}{l}\text { No. of eagles } \\
\text { per plot }\end{array}$ & $\begin{array}{l}\text { Contact time per plot } \\
(\mathrm{min})\end{array}$ \\
\hline Mangrove and coastal forest (6) & $27 \pm 27$ & $0.78 \pm 0.74$ & $0 \pm 0$ & $0 \pm 0$ \\
Cultivated land (5) & $102 \pm 72$ & $0.24 \pm 0.21$ & $0.20 \pm 0.45$ & $0.80 \pm 1.79$ \\
Shrub and degraded forest (5) & $126 \pm 98$ & $0.62 \pm 0.56$ & $1.20 \pm 1.30$ & $4.40 \pm 6.80$ \\
Tall forest (12) & $173 \pm 130$ & $0.97 \pm 1.09$ & $1.25 \pm 1.30$ & $7.54 \pm 14.8$ \\
\hline
\end{tabular}

Values are means \pm 1 SD. 
and $F_{1,10}=0.48, P=0.50$ for number of eagles per plot and contact time per plot, respectively). In other forest eagles juveniles and immatures often venture out into secondary or disturbed habitats (Nijman and van Balen 2003), but the number of juveniles and immatures that could be reliably aged did not allow testing for differences in the ratio of adults to juveniles and immatures between disturbed and undisturbed sites.

\section{Threats}

Bawean is approximately one-third covered in forest, with an additional fifth covered in teak and other forest-like plantations. Burning of the undergrowth occurs frequently in the teak forest but also in, and surrounding, the strict nature reserve. Many of the larger trees in the teak plantations had recently been (illegally) logged, and illegal logging in the remaining natural forest was widespread.

Since Bawean Serpent-eagles do not seem to make use of mangrove or coastal forest, the two small offshore strict nature reserves are of no relevance to the protection of the eagle. Some good forest remained in the terrestrial nature reserve but it was completely surrounded by cultivated land. Access was open (despite strict laws prohibiting it), collection of firewood was widespread, and during each of my three visits to the reserve small teams of men with chainsaws were rapidly opening up the forest. As with the strict nature reserve, the wildlife reserve seemed open for the public, with the sound of chainsaws omnipresent.

Of the 15 interviewees (all but three born on Bawean, average age 39 years, range 22-67 years), II considered the Bawean Serpent-eagle to be less common at present than in the past whereas three considered it equally common or equally rare. Of these latter three interviewees, two (a police officer and an army officer, both born on Java) were not aware of any other environmental problems (logging, encroachment into reserves, hunting) on the island or strongly denied them. According to those who considered the Bawean Serpent-eagle to be less common at present, the decline started to become evident 10-12 years ago (1990-1992: 2 respondents) or 4-5 years ago, coinciding with the beginning of the economic crisis and the downfall of former president Suharto (1997-1998: 4 respondents). Of the interviewees who could identify a possible cause of the decline, nine pointed without hesitation to an increase in (recreational) hunting. As secondary causes logging (2), dispersal to other parts of the island (2) and keeping birds as pets (I) were mentioned. Apparently (air) rifles became widely available on the island only 5-10 years ago, and shooting Bawean Serpenteagles was now both popular and widespread. During the surveys in the forest, six men were encountered carrying air rifles, and four of the interviewees said that they had shot eagles in the past.

\section{Population statistics}

Based on the distribution of forest, the abundance of the serpent-eagles, and especially the distribution of displaying pairs, there seem to be three sections of the island that still offer good habitat (Figure 5). These sections are by and large covered in tall forest, with smaller sections in shrub and degraded forest. The largest of these measures some $48 \mathrm{~km}^{2}$, is situated in the central mountainous part of the island and includes both the strict nature reserve and the wildlife reserve. Two smaller sections are south 


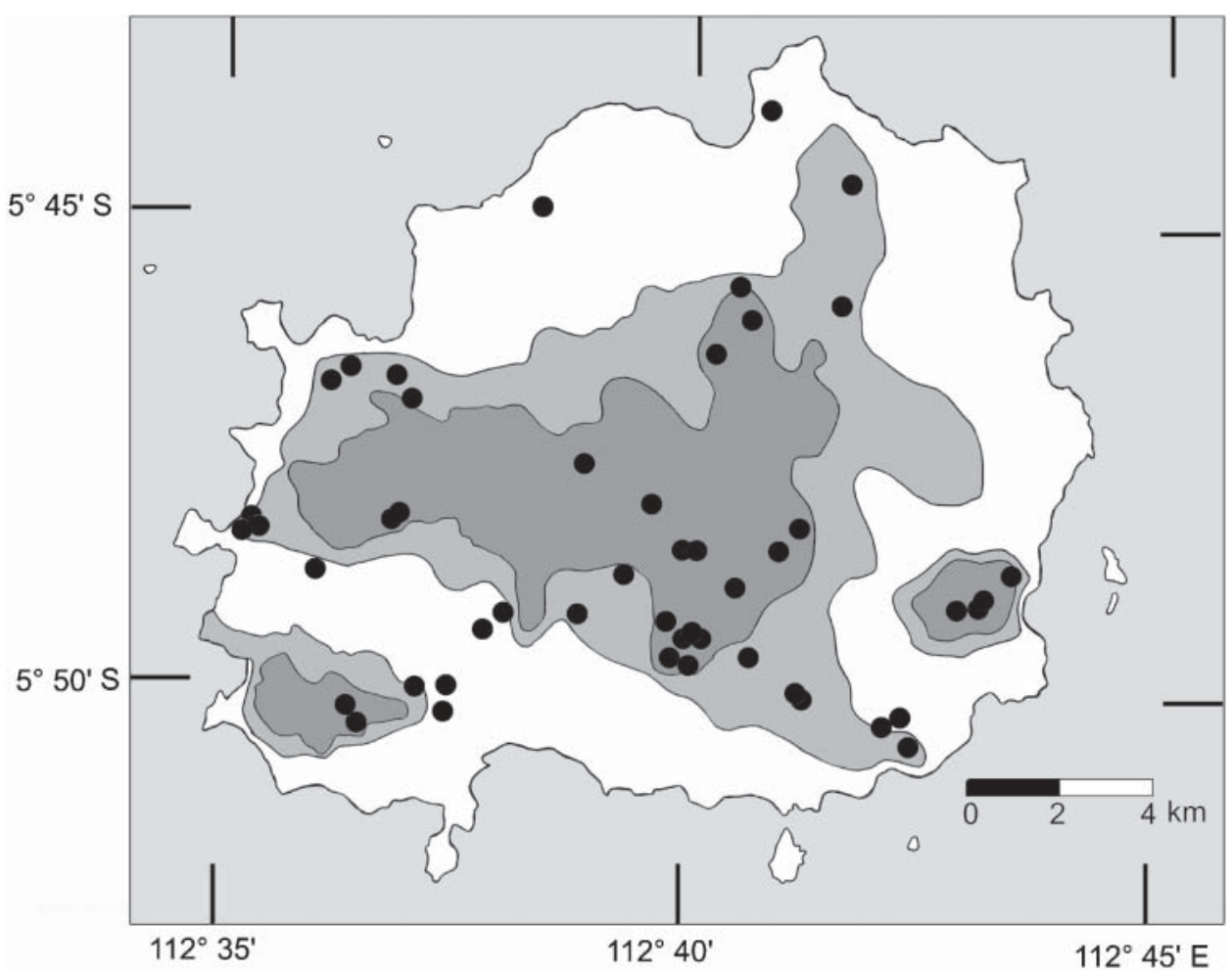

Figure 5. Distribution of Bawean Serpent-eagles Spilornus baweanus with an assessment of habitat quality. In dark grey are areas covered in good habitat and in light grey those with marginal habitat (see text for details). Dots refer to sightings of eagles upon first encounter.

of the village of Kumalasa $\left(6 \mathrm{~km}^{2}\right)$ and near Mount Brakas $\left(4 \mathrm{~km}^{2}\right)$. Surrounding these sections is a wide band of marginal habitat covering essentially all land $>200 \mathrm{~m}$ a.s.l. This includes mostly shrub and degraded forest and teak plantations. The available habitat, both 'good' and 'marginal', therefore totals some $92 \mathrm{~km}^{2}$. A working density of I pair per $3 \mathrm{~km}^{2}$ for 'good' habitat and I pair per $5 \mathrm{~km}^{2}$ for 'marginal' habitat leads to a total population size of $26-30$ pairs. If we add some 4-7 pairs for small forest patches not included in the above estimate, the total population comprises some $60-75$ paired adults.

\section{Discussion}

\section{Distribution and abundance}

Although the present survey was short in duration (15 days), the small size of Bawean and its accessibility combined with the ease of observation of the Bawean Serpenteagle allows a relatively accurate assessment of its distribution and abundance to be made. The eagle was observed in all parts of the island and was recorded almost daily. Hoogerwerf (1967) recorded the Bawean Serpent-eagle on less than half his field days $(17 / 40)$ but noted that the species was recorded from the surroundings of most of 
their 10 camping sites, giving the impression it was fairly widely distributed. The rather more frequent recording of the species in the present study compared with that of Hoogerwerf (1967) is probably due to more focused research rather than an increase in numbers.

In its behaviour and ecology, the Bawean Serpent-eagles does not differ significantly from its congeners on nearby Java, Sumatra, Borneo or the Thai-Malay Peninsula (MacKinnon et al. 1998, Wells 1999, V. Nijman unpubl. data); birds were mostly observed in singles or pairs, and soaring usually occurred in late morning when the birds are also most vocal. The bird was noticeably less abundant in cultivated areas compared with forest. Although the Bawean Serpent-eagle is not a true forest eagle (almost a fifth of the eagles were observed in cultivated land and many of the eagles initially observed in forest ventured out of it when soaring), it is clear that when the forest was absent so was the eagle. However, unlike its congeners, the Bawean Serpent-eagle was surprisingly absent in coastal and mangrove forest. Wells (1999) noted that Crested Serpent-eagles in the Thai-Malay Peninsula were particularly abundant in mangrove forests, possibly as a result of the easy availability at low tide of Dog-faced Watersnakes Cerberus rhynchops. In parts of Java Crested Serpenteagles can also be fairly abundant in coastal forest (V. Nijman pers. obs.). Since the widely distributed seasnake-predating White-bellied Sea-eagle Haliaeetus leucogaster is absent from Bawean (Nijman 2004b) it was rather surprising not to observe even a single Bawean Serpent-eagle in these coastal habitat types.

The home range size estimates of Bawean Serpent-eagles, although admittedly crude, are within the range reported for other members of the genus (Ferguson-Lees and Christie 2001), and despite the absence of any other eagles the species did not seem to be particularly abundant.

\section{Threat assessment}

Unlike the situation on nearby Java, where especially habitat loss (Nijman 2004a) and capturing eagles for the domestic pet trade are the main threats to eagles (van Balen et al. 1999), the most prominent threat to the Bawean Serpent-eagle appears to be hunting. Many islanders possessed air rifles and, especially around villages, men and boys were seen 'practising' their skills by aiming at the smaller birds and other animals. During late morning the eagles would frequently soar, often near villages, and during the early phase of rising or at the later phase of the descent the eagles make easy targets for those willing to shoot them, even with only an air rifle. The abundance of eagles did not seem to be influenced by the proximity of villages and several eagles were seen perched in village areas: this points to the adaptability of the eagle but at the same time will make the species especially vulnerable to being shot by villagers.

More than half the interviewees who indicated that the Bawean Serpent-eagle was experiencing a decline in abundance considered this a recent phenomenon, dating back less than a decade at the most. This coincided with the arrival of air rifles and a general decrease in law enforcement after the downfall of former President Suharto (Jepson et al. 2001). Hunting thus seems a relatively new threat to the Bawean Serpent-eagle and wildlife in general (cf. Hoogerwerf 1966, 1967, Sitwell 1970, Blouch and Admosurdirdjo 1979) and its impact is expected to be considerable. 


\section{Population status and management}

For comparison with the current population estimate, it is worthwhile assessing what the original population size of the Bawean Serpent-eagle may have been. There are no indications that the species occurs on any other island in the Java Sea (e.g. Karimunjawa, Madura or Kangean: MacKinnon et al. 1998, Nijman 2004b) and thus the species probably evolved in situ on an island of $190 \mathrm{~km}^{2}$ (although during glacial periods, when sea levels were lower than at present, the island may have been considerably larger and may even have been intermittently connected to mainland Java). Until the fourteenth century Bawean was uninhabited by humans and thus before that was probably fully covered in forest. If densities in these pristine conditions were 1.5 times as high as at present in 'good' habitat (i.e. I pair per $2 \mathrm{~km}^{2}$ as they would probably reach higher densities in large, continuous stretches of forest and persecution by humans would be absent), a maximum of a hundred pairs may have been present. Some $40 \%$ of this estimated original total remains.

Similarly small (historic) population sizes in raptors have been reported for the Socorro Red-tailed Hawk Buteo jamaicensis socorroensis of Socorro Island (Walter 1990), the Cape Verde Kite Milvus fasciicauda of the Cape Verde Islands (FergusonLees and Christie 2001, Sangster 2000), and possibly Forbes Kite Leptodon forbesi of north-east Brazil (Ferguson-Lees and Christie 2001). Just like the Bawean Serpenteagle, the latter two species are currently among the most threatened birds of prey in the world, whereas the Socorro Red-tailed Hawk seems to be fairly common within its restricted range.

Although Bawean was scarcely populated by humans in the first few centuries of being inhabited, the human population increased greatly from the beginning of the nineteenth century (1813: 11,000 inhabitants; 1824: 21,000; 1958: 48,000; 1979: 69,000; 2002: 64,000; data from Hoogerwerf 1966, Blouch and Admosurdirdjo 1979, Department of Agriculture Bawean, unpubl. data). If this increase was accompanied by a similar decrease in forested land, habitat loss for Bawean Serpent-eagles really took off in the second half of the nineteenth century, very similar to the situation on Java (Whitten et al. 1996). This assertion concurs with reports from early explorers who visited Bawean (summarized in Hoogerwerf 1966): in the early nineteenth century they already noted that, apart from in the highlands, there was hardly any real forest left on the island and at various times timber for boat construction had to be imported from Java. Due to unclear reasons at the beginning of the twentieth century, forest in parts of Bawean was allowed to regenerate such that it had clearly gained in size by the mid-twentieth century, although large parts of the island were still deforested (Hoogerwerf 1966). At present less than a third of the island offers potential habitat for the eagle, but little of this is adequately protected.

Only a small percentage of the species' remaining habitat is included in the island's protected area network; the protection of habitat and the eagles themselves is insufficient and consequently the status of Bawean Serpent-eagle is a cause for great concern. At present the Bawean Serpent-eagle has not been subject to a threat assessment (as it was considered a subspecies of the Crested Serpent-eagle), and it is therefore not included in the IUCN Red List of Threatened Species or BirdLife's list of threatened birds (BirdLife International 2000). On the basis of my study, and applying the IUCN threat criteria (IUCN 2001), I recommend the Bawean Serpent-eagle be categorized as Critically Endangered as it is facing an extremely high risk of extinction in the wild 
according to two criteria: B $\mathrm{Iab}(\mathrm{iii}, \mathrm{v})$, i.e. area of occurrence $<100 \mathrm{~km}^{2}$, with the population known to exist at only a single location (a) and a continuing decline (b) in area, extent and/or quality of habitat (iii) and number of mature individuals (v); and $\mathrm{C}_{1}, 2$ (ii), i.e. population size estimated to number $<250$ mature individuals and an estimated continuing decline of $<25 \%$ within one generation (c. IO years) ( 1 ), and a continuing decline in numbers of mature individuals (2), with all mature individuals in one subpopulation (ii).

Indonesian law protects all diurnal birds of prey, including the Bawean Serpenteagle. However, within the context of the present political and economic situation in the country, and given the numerous examples of inadequate species and habitat conservation throughout Indonesia, the survival chance of the Bawean Serpent-eagle is slim. In order to safeguard the species it is of utmost importance to quickly formulate a conservation strategy. A first priority would be to bring recreational hunting to a complete halt, after which attention should be directed towards more effective habitat protection. This is probably best achieved by an integrated project in which a dedicated and fully mandated conservation body cooperates with local and regional (conservation) authorities and local NGOs. It is to be hoped that one of the many local conservation NGOs that have emerged on Java in recent years will take up the daunting task of instigating such an initiative.

\section{Acknowledgements}

The study was conducted in cooperation with the Directorate General for Forest Protection and Nature Conservation (PHKA), and under sponsorship of the Indonesian Institute for Sciences (LIPI). I would like to thank the staff at the Regional Agency for the Conservation of Natural Resources (BKSDA) in Sangkapura, and especially Pak Nur Syamsi, for their cooperation. M. Lammertink, Bas van Balen and an anonymous reviewer are thanked for constructive comments.

\section{References}

Amadon, D. (1974) Taxonomic notes on the Serpent-eagles of the genus Spilornis. Bull. Br. Ornithol. Club 94: 159-163.

BirdLife International (2000) Threatened birds of the world. Barcelona and Cambridge, U.K.: Lynx Edicions and BirdLife International.

Blouch, R. A. and Admosudirdjo, S. (1979) Usulan suaka margasatwa Pulau Bawean, pedoman pengolaan. Bogor: World Wildlife Fund.

Brown, L. and Amadon, D. (1968) Eagles, hawks and falcons of the world. Feltham: Country Life Books.

Burton, P. (1989) Birds of prey. New York: Gallery Book.

Ferguson-Lees, J. and Christie, D. A. (2001) Raptors of the world. London: Christopher Helm.

Hoogerwerf, A. (1962) Notes on Indonesian birds with special reference to the avifauna of Java and the surrounding small islands (I, II, III). Treubia 26: 11-291.

Hoogerwerf, A. (1965) Vogels van Java. Unpublished manuscript lodged at the Zoological Museum Amsterdam.

Hoogerwerf, A. (1966) Notes on the island of Bawean (Java Sea) with special reference to the birds (I, II). Nat. Hist. Bull. Siam Soc. 21: 313-340.

Hoogerwerf, A. (1967) Notes on the island of Bawean (Java Sea) with special reference to the birds (III, IV). Nat. Hist. Bull. Siam Soc 22: 15-103. 
IUCN (2001) IUCN Red List of threatened species: 2001 Categories \& Criteria (version 3.1). Gland, Switzerland: IUCN. [https://www.redlist.org/info/categories_criteria20o1.html, accessed 13 January 2004]

Jepson, P., Jarvie, J. K., MacKinnon, K. and Monk, K. A. (2001) The end of Indonesia's lowland forests? Science 292: 859-861.

MacKinnon, J., Smiet, F. and Artha, M. B. (1982) A national conservation plan for Indonesia. Volume III: Java and Bali. Bogor: FAO.

MacKinnon, J. R., Phillips, K. and van Balen, S. (1998) Burung-burung di Sumatera, Jawa, Bali dan Kalimantan (termasuk Sabah, Sarawak dan Brunei Darussalam). Revised Indonesian edition. Jakarta: Puslitbang Biologi-LIPI.

Meise, W. (1939) Ueber die Schlangenadler der gattung Spilornis Gray. J. Ornithol. 87: 65-74.

Nijman, V. (2004a) Habitat segregation in two congeneric hawk-eagles (Spizaetus bartelsi and S. cirrhatus) in Java. J. Trop. Ecol. 20: 105-111.

Nijman, V. (2004b) Survey on birds of prey and owls (Falconiformes and Strigiformes) on Bawean, Java Sea, with records of three species new to the island. Raffles Bull. Zool. 52: $647-651$.

Nijman, V. and van Balen, S. (2003) Wandering stars: age-related habitat use and dispersal of Javan Hawk-eagles (Spizaetus bartelsi). J. Ornithol. 144: 451-458.

Oberholsen, H. C. (1917) The birds of Bawean Island, Java Sea. Proc. U.S. Nat. Mus. 52: $183-198$.

Sangster, G. (2000) Taxonomic stability and avian extinctions. Conserv. Biol. 14: 579-581.

Sitwell, N. (1970) Bawean Island expedition. Animals 294: 389-393.

Sokal, R. R. and Rohlf, F. J. (1995) Biometry: the principles and practise of statistics in biological research. 3 rd edition. New York: W. H. Freeman.

Stresemann, E. (1959a) Die Gliederung des Schlangenadler-Gattung Spilornis. Vierteljahrsschrift der Naturforschenden Gesellschaft Zürich 104: 208-213.

Stresemann, E. (1959b) Die typische Lokalität von Spilornis bassus. J. Ornithol. 100: 355.

van Balen, S., Nijman, V. and Prins, H. H. T. (2000) The Javan Hawk-eagle: misconceptions about rareness and threat. Biol. Conserv. 96: 297-304.

Vorderman, A. G. (1892) Bijdrage tot de kennis der avifauna van het eiland Bawean. Natuurk. Tijdschr. Ned.-Indië 51: 417-422.

Walter, H. S. (1990) Small viable population: the Red-tailed hawk of Socorro Island. Conserv. Biol. 4: 44I-443.

Wells D. R. (1999). The birds of the Thai-Malay Peninsula. Volume 1: Non-passerines. London: Academic Press.

Whitten, A. J., Soeriaatmadja, R. E. and Afiff, S. A. (1996) The ecology of Java and Bali. Singapore: Periplus Editions The ecology of Indonesia series, volume II.

\section{VINCENT NIJMAN}

Zoological Museum, University of Amsterdam, P. O. Box 94766, 1090 GT Amsterdam, the Netherlands.E-mail:nijman@science.uva.nl 